\title{
OLD LICENSES AND NEW USES MOTION PICTURE AND TELEVISION RIGHTS
}

\author{
MORrIs E. COHN*
}

As technical advances continue and the means for bringing together entertainment and audience improve, the monetary values involved increase, and literary property documents seek to assure certainty by length, detail, enumeration, description, and endless repetition. When disputes arise they are more often of sufficient proportion to justify litigation.

In the courtroom the judge is prone to approach a disputed writing with a set of postulates which, because they remain unspoken, escape analysis and criticism, and thus may lead to undirected conclusions. Among these postulates, it is safe to say, are these: that words or phrases such as "motion picture rights," "dramatic rights," and "exclusive rights" had a fixed meaning in the minds of the parties and were intended, in the disputed writings, to convey a definite discoverable meaning; ${ }^{1}$ and that such phrases have "correct" meanings, not always the same as the intended meanings, which a court may under some circumstances attach to the documents. More fundamental than these postulates is the judicial faith which assumes that once the dispute concerning the words is solved, the conflict is gone, justice automatically comes into being, and each litigant will receive his just due.

It is the purpose of this paper to appraise these postulates and that faith by an examination of the decisions rendered in literary property cases involving disputed licenses and assignments. The construction of current title and use documents will, if one may judge by the history of literary property decisions, be significantly affected by the fact that television is a relatively new use and may not have been known (or if known, then was disregarded) when the questioned instrument was executed. This paper will examine the decisions which came out of the commercial development of motion pictures and "talkies," and the few decisions involving television uses. It is the thesis of this writer that the courts have not yet evolved a sound principle for dealing with the problems arising from new uses, nor even a reliable rule, and that a frank avowal of the economic factors involved, with opportunity for resolving issues so raised, must be attempted before a more satisfactory solution can be attained.

\footnotetext{
* Member of the California bar; Counsel, Hollywood Local, Radio and Television Dircetors Guild; formerly counsel for Screen Writers Guild and for Radio Writers Guild; author, articles entitled "Moral Rights," and "Literary Property: The Question of Ownership," and of other pieces dealing with literary property.

${ }^{1}$ E.g., Norman v. Century Athletic Club, 193 Md. 584, 69 A.2d 466 (1949), concluding that "broadcast" in a license to use a sports arena meant a radio broadcast and did not include transmission by television.
} 
The commercial success of television has brought numerous problems into the field of literary property and copyright. Some of these problems are repetitions in modern dress of those raised earlier in the century by the development of silent films, later by the addition of dialogue to films, and still later by radio broadcasting. Other problems are new, and arise out of the peculiarities of television production. It is important, therefore, not only to have in mind earlier decisions in analogous situations, but also to have some understanding of the mechanics of television production so far as relevant to the literary property and "rights" problems which are involved.

Except for spot news, sports events, panel shows, and portions of audience participation shows, most television programs have their origins in prepared scripts. The particular script may have been written expressly for the television program, or it may originally have been a short story, published or unpublished, or a play, or a screenplay. If the original script was not written for television, it will almost certainly be re-written and adapted to fit the peculiar requirements of television, most often the half-hour show, broken by commercials, to be produced on facilities available to the television producer. The original work may have been registered for copyright as a book, or in a periodical; if it was previously produced as a motion picture, the film version will have been registered for copyright. Rights in literary property thus pyramid and interlock in confusing complexity. Dramatic rights in a novel may be split off the copyright; when the play is written and performed, it may be printed, and the play may be registered for copyright; motion picture rights in the play or in the novel, or in both, may be assigned, and the film so produced will also be registered for copyright. The cautious telecaster will telecast such a film only under cover of a swarm of licenses and from a bunker of indemnity agreements. $^{2}$

The television program itself may reach the air as a "live telecast"-that is produced by living players before the electronic camera-or as a "recorded telecast" -that is by the projection of a film (or, more recently, by the use of magnetic tape). Sometimes the program is assembled of various units, some film, some live. When the program is "live," and often when one or more of the units is "live," most network stations today produce a kinescope or television recording (a "kine" or "T. V. R.") of the program, by recording on film the image and sound track at the moment of the telecast. The film is a kind of packaging of the program; it may be duplicated by usual printing methods, and the film and its prints may themselves be telecast.

It is worth noting that the exercise of a "television right" need not, like dramatization or filming, produce a new work or a new version of another work. It is true that television use may be facilitated or enhanced by a revision or adaptation of an existing work; but the right to prepare a television script is not what is ordinarily meant by "television rights," nor does the preparation of the scripts carry the major

${ }^{3}$ Cf. Harry P. Warner, Radio and Television Law il24 (r949). 
economic significance. Television is a method of presenting a work to an audience, and a television right is a right to present a work by that method. The work itself may, but need not, be re-written. Even if it were a play, it could be read by a single announcer; or the printed page might itself be photographed and telecast, to be read by the viewer. What is significant to the author, the proprietor, the licensor, and all others interested is that a new source of revenue has been tapped by the invention of television.

Before entering into a discussion of the decisions involving disputed rights, it is well to consider the general nature of the documents most commonly in use for the transfer of rights and licensing of uses. Disputes arise from specific writings, and proffered solutions cannot ignore the record of the transaction. This writer maintains that the paper and its ink do not always make the just solution manifest; and that rules of construction often create presumptions merely, which are primarily devices for expediency and are not necessarily reliable guides to justice. Nevertheless, the decisions demonstrate that the character of the instrument is one of the factors in the disputes which have arisen. For example, the implied negative covenant doctrine (which is discussed later) has been applied only in cases involving exclusive licenses of specific uses, and has never been held applicable in other forms.

One common form is the "assignment of all rights." By this instrument the author, or proprietor, conveys to another the work, the copyright, and every right for use which may in any way be derived from the work. The author parts with everything, reserves nothing. Barring unusual or doubtful language, such a conveyance is held to transfer all rights to the assignee or grantee, without regard to economic effect of new uses or new methods of exploitation beyond the contemplation of the original parties. ${ }^{3}$

It is in those instances in which the instrument conveys less than the whole of the rights that disputes have most often arisen. In strict contemplation of law, such an instrument purporting to convey less than the whole, actually conveys nothing, that is, no interest in the work itself. The avowed reason is that the copyright is indivisible and may not be split or conveyed in parts, and these reasons are often said to be based on the fact that the copyright statutes do not recognize partial assignments. ${ }^{3}$ However, it has also been said that common law copyright is indivisible, ${ }^{6}$ and the same was said of copyright under the English law ${ }^{7}$ prior to the statute of Igrr. ${ }^{8}$

${ }^{3}$ Grant v. Kellogg, 154 F. 2d 59 (2d Cir. 1946); Dam v. Kirk La Shelle, I75 Fed. 902 (2d Cir. xgro); American Law Book Co. v. Chamberlayn, I65 Fed. 312 (2d Cir. Ig08); and sec Granz v. Harris, 98 F. Supp. 906 (S. D. N. Y. 195I); Vargas v. Esquire, 164 F. 2d 522 (7th Cir. 1947).

'Empire City Amusement Co. v. Wilton, r34 Fed. 132 (C. C. D. Mass. I903); M. Witmark \& Sons v. Pastime Amusement Co., 298 Fed. 470 (E. D. S. Car. 1924).

${ }^{5}$ See sections 28, 30, 32, 6I STAT. 652 (I947), 17 U. S. C. \$\$28, 30, 32 (Supp. 1952).

Keene v. Wheatley, 14 Fed. Cas. 180 , No. 7,644 (C. C. E. D. Pa. I86I); Palmer v. De Witt, 47 N. Y. $532,54 \mathrm{I}$ (1872).

${ }^{7}$ Power v. Walker, 3 M. \& S. 7, 105 Eng. Rep. 514 (K. B. I814); Lucas v. Cooke, I3 Ch. D. 872 ( 1880 ); Shepherd v. Conquest, I7 C. B. 427 , I39 Eng. Rep. II 40 (C. P. 1856); Copyright Act, I9II, I \& 2 GEo. 5 , c. $46, \$ 5(a)$.

8 There are statements to the contrary. Eaton S. Drone, A Treatise on the Law of Property in 
The distinction between assignments of the whole and partial assignments, if it exists at all, is becoming largely a verbal one; ${ }^{9}$ partial assignments or licenses may themselves be made assignable, ${ }^{10}$ and the licensee may now bring suit in his own name by meeting procedural requirements. ${ }^{11}$

Pertinent to the question under discussion is the principle, often applied in instruments which grant less than the whole: enumeration prevents implication, that is, if the instrument particularizes the rights granted, no others will pass. ${ }^{12}$ Such a rule does not dispose of the argument that an expressed right may include another, as, for example, that "dramatic rights" include "motion picture rights"; nor does it help the search for fair play when new uses or new methods of presentation have appeared since the instruments were written.

One other category of instruments deserves mention. It is the assignment of copyright (or of the right to copyright) with reservation of specified rights to the assignor. ${ }^{13}$ In such an instrument the reserved rights, rather than those granted, would be enumerated, and presumably subject to the effect of the expressio unius rule.

It is, of course, impossible to predict all of the literary property questions which will be raised by the advent of television. Even those that have already become the subject of concern in the entertainment industry are too many and too complex to be considered in a single article, particularly in the absence of definitive judicial decision. A few are, however, worth noting, if only for consideration by others at a later time. Apart from express language, may the holder of motion picture rights exhibit the film on television? Does the practice of television stations of making a kinescope or a T.V.R. of a "live" rendition of a literary work violate the exclusivity of a prior motion picture license of the same work? While the present article will refer to the few decisions touching on the use of motion picture films on television, it is primarily concerned with the interpretation of title and use documents affecting rights in literary works. However, it is believed that the discussion of old instru-

Intellectual Productions in Great Britain and the United States 334 (1879); Black v. Allen, 42 Fcd. 6r8, 62 I (C. C. S. D. N. Y. r890); Roberts v. Meyers, 20 Fed. Cas. 898, No. II,906 (C. C. D. Mass. 1860); Werkmeister v. Springer Lithographing Co., 63 Fed. 808 (C. C. S. D. N. Y. I894).

- Current terminology reflects the change. Licenses are commonly, even by lawyers, called grants and conveyances, licensors are called grantors. This paper uses the terms interchangeably, except where a distinction is required.

${ }^{10}$ If the license involves "personal trust and confidence," it is not assignable; otherwise it may be. In re D. H. McBride \& Co., 132 Fed. 285, 288 (S. D. N. Y. 1904); and cf. In re Hawley-Dresser Co., 132 Fed. Iro2 (S. D. N. Y. I904).

${ }^{11}$ Photo Drama Motion Picture Co. v. Social Uplift Film Corp., 213 Fed. 374 (S. D. N. Y. 1914); Buck v. Elm Lodge, 83 F. 2d $20 \mathrm{r}$ (2d Cir. 1936); Stephens v. Howells Sales Co., x6 F. $2 \mathrm{~d} 805$ (S. D. N. Y. 1926); Machaty v. Astra Pictures, 197 F. $2 d$ I38 (2d Cir. 1952); Widenski v. ShapiroBernstein Co., 147 F. 2d 909 (Ist Cir. 1945).

${ }^{23}$ T. B. Harms and Francis, Day \& Hunter v. Stern, 229 Fed. 42 (2d Cir. 1915); Klein v. Beach, 232 Fed. 240 (S. D. N. Y. IgI6); Harper Bros. v. Klaw, 232 Fed. 609 (S. D. N. Y. I916); Manners v.Morosco, 258 Fed. 557 (2d Cir. I9I9), rev'd, 252 U. S. 317 (1920).

${ }^{13}$ Ford v. Charles E. Blaney Amusement Co., 148 Fed. 642 (C. C. S. D. N. Y. I906); Fitch v. Young, 230 Fed. 743 (S. D. N. Y. r9r6); Brady v. Reliance Motion Picture Corp., 229 Fed. I37 (2d Cir. I916). 
ments as affected by new uses may be pertinent to the conflicting interests of motion picture rights and television use.

Prior to I9I2 the copyright statutes made no reference to motion pictures, ${ }^{14}$ although the art had been known in a primitive form for over three decades. ${ }^{15}$ There was, of course, considerable traffic in dramatic rights and some stirrings in the production of film. The status of motion pictures was still so uncertain that it required the decision of the Supreme Court in Kalem Co. v. Harper Bros., ${ }^{10}$ to establish that an unauthorized motion picture based on a novel was an infringement of the copyright of that novel. The Supreme Court held that the motion picture, depicting brief scenes from the novel, held together by narrative, constituted a dramatization of the novel, a privilege granted exclusively to the copyright holder; ${ }^{17}$ consequently the motion picture was an infringement.

If a motion picture is a dramatization, ${ }^{18}$ it seemed to many that the holder of exclusive "dramatic rights" automatically had the exclusive right to produce a motion picture. Judge Learned Hand assumed, without deciding, in one case that an assignment of dramatic rights carried with it motion picture rights, though he held that a notice of assignment of dramatic rights did not constitute notice of assignment of motion picture rights. ${ }^{10}$ In so construing the notice, he relied expressly on the I9I2 amendment to the Copyright Act which, he said, separated the motion picture rights from the dramatic rights. ${ }^{20}$

Other decisions said or held that a grant of stage rights or of dramatic rights carried the motion picture rights, even though in some cases the conveyances were written before motion pictures were known. ${ }^{21}$ However, it was not long before a contrary view appeared. The courts said that motion picture rights were not necessarily, or were not at all, embraced in dramatic rights. In some cases the reason given was the I9I2 amendment to the Copyright Act, and in some cases it was said that because motion pictures had become better known it could be assumed

24 The Act, however, provided for registration of photographs, and some of the earlier motion pictures had been held subject to copyright as photographs. Harper Bros. v. Kalem Co., 169 Fed. 6r (2d Cir. 1909), affd on other grounds, 222 U. S. 55 (r9II). See Edison v. Lubin, r22 Fed. 240 (3d Cir. 1903), concerning a 300 foot motion picture of the launching of Kaiser Wilhelm's yacht which was copyrighted as a photograph. See also American Mutoscope and Biograph Co. v. Edison Mfg. Co., 137 Fed. 262 (C. C. D. N. J. 1905).

${ }^{15}$ The kinetoscope was invented in 1889. Note, Motion Picture Copyright, 25 WASH. U. L. Q. 554 (1940).

${ }_{10} 222$ U. S. 55 (I9II).

${ }^{27}$ Sec. I (b), 6I STAT. 652 (I947), I7 U. S. C. \$I(b) (Supp. 1952).

${ }^{18}$ A motion picture photoplay has since been held to be a "dramatic work" under the terms of Scc. I(d) of the Copyright Act. Universal Pictures v. Harold Lloyd Corporation, I62 F. 2d 359 (9th Cir. 1947); Vitaphone Corporation v. Hutchinson Amusement Co., 19 F. Supp. 359 (D. Mass. 1937), 28 F. Supp. 526 (D. Mass. 1939).

${ }^{10}$ Photo Drama Motion Picture Co. v. Social Uplift Film Corp., 213 Fed. 374 (S. D. N. Y. 1914).

${ }^{20}$ The amendment of Aug. 24, Igr2 (37 STAT. 488) added classifications "l" and " $m$ " to Sce. 5 of the Act. Those classifications are: "l," "motion picture photoplays"; and "m," "motion pictures other than photoplays." I7 U. S. C. $\$ 5(1)$ and (m).

${ }^{22}$ Hart v. Fox, I66 N. Y. Supp. 793 (Sup. Ct. 1917); Frohman v. Fitch, 164 App. Div. 231, 149 N. Y. Supp. 633 (Ist Dep't 1914); Lipzin v. Gordon, I66 N. Y. Supp. 792 (Sup. Ct. I915); cf. Gillette v. Stoll Film Co., 120 Misc. 850, 200 N. Y. Supp. 787 (Sup. Ct. 1922). English decisions also so held: British Actors Film Co. v. Glover, [1918] I K. B. 299. 
that the parties would have used direct language in granting motion picture rights if they had intended to grant them. ${ }^{22}$

A majority of the Supreme Court, in Manners $v$. Morosco, ${ }^{23}$ reversed the two courts below in an opinion by Holmes, saying:

The thing granted was "the sole and exclusive license and liberty to produce, perform, and represent" the play within the territorial limits stated, subject to the other terms of the contract. It may be assumed that those words might carry the right to represent the play in moving pictures if the other terms pointed that way, but to our mind they are inconsistent with any such intent.

Before attempting any generalizations from those decisions, it is well to examine the conduct of the courts in the analogous controversies which arose when sound and dialogue were added to motion pictures. The question usually arose in determining whether a license to produce motion pictures authorized the licensee to produce a "talkie," a motion picture with dialogue. ${ }^{24}$

One of the first decisions seems to have been influenced by the early motion picture determinations, holding "motion picture rights" embraced within "dramatic rights."

In I933 a licensee of dramatic and motion picture rights got an injunction to prevent the production of a "talkie," the court holding that the plaintiff owned the talking picture rights by reason of his ownership of the dramatic and motion picture rights. ${ }^{25}$ "Where the same person holds both the silent picture rights and the dramatic rights he owns everything necessary to the making of a talking motion picture. ..."26 The court's reasoning seems to be an additive process: dialogue rights (from dramatic rights) plus film rights (from motion picture rights) equal talking film rights. ${ }^{27}$ The fact that a new use was at stake, with large economic consequences to author and licensee, was apparently disregarded.

A few years later the leading case on the subject followed a similar course. The Second Circuit Court of Appeals had before $\mathrm{it}^{28}$ a grant of motion picture rights executed in I923 when, as the court declared, "talkies" were in the experimental stage and were not known commercially; the court also had before it an express grant of talking picture rights executed in I935. It was held that the earlier grant

${ }^{23}$ Klein v. Beach, 232 Fed. 240 (S. D. N. Y. I9r6), aff'd, 239 Fed. ro8 (2d Cir. 19r7); Harper Bros. v. Klaw, 232 Fed. 609 (S. D. N. Y. IgI6); Manners v. Morosco, 252 U. S. 317 (I920); Macloon v. Vitagraph, 30 F. 2d 634 (2d Cir. I929).

${ }^{23} 252$ U. S. 317 , at $325-326$ (x920).

26 It is worth noting that in Underhill v. Schenck, II4 Misc. 520, I87 N. Y. Supp. 589 (Sup. Ct. I921), the "Passion Flower" case, in dealing with the question whether the right to perform a play in English carried motion picture rights, it was said (p. 59x): “. . a motion picture play is not a performance in the English or in any other language."

${ }^{25}$ Cinema Corporation of America v. De Mille, 149 Misc. 358,267 N. Y. Supp. 327 (Sup. Ct. r933).

so Id. at 328 .

${ }^{27}$ In Rosenberg v. Lesser, 20 Copyrigert Bulzertin 599 (1934), the Superior Court for Los Angeles County reached a similar conclusion from an assignment of "motion picture rights, dramatic rights, and spoken stage rights."

${ }^{18}$ In L. C. Page \& Co. v. Fox Film Corporation, 83 F. $2 d$ Ig6 (2d Cir. I936). 
had conveyed the "talkie" rights. ${ }^{29}$ The magic attributable to words as independently dynamic instruments is exemplified by the following statement of opinion: $:^{30}$

The mere fact that the species "talkies" may have been unknown and not within the contemplation of the parties in their description of the generic "moving pictures" does not prevent the latter from comprehending the former. (Italics supplied.)

The decisions involving television rights are too few and too scattered to warrant conclusions. They do, however, deserve examination as indicating the nature of the problems to be presented, the source of disputes, and possibly judicial bent.

In Wexley v. KTTV, Inc., ${ }^{31}$ the author had assigned the "complete, entire ... motion picture rights" in the play, The Last Mile, including the right to lease, exhibit, exploit, transmit, and deal in motion picture versions, in any manner and method now or hereafter known. By the instrument the author had reserved the stage rights and "television rights unaccompanied by a visual representation of the play,"32 as well as the right after fifteen years to televise live performances of the play. The question presented was whether the assignment authorized the assignee to telecast the film. Judge Byrne construed the peculiar language of the instrument to mean that it did. ${ }^{33}$ Wexley urged that the reservation quoted retained for him the right to exhibit motion pictures on television, because a motion picture is not a visual representation of the play. Judge Byrne said, however (p. 559), "That a motion picture of a play exhibited on television is a visual representation of the play cannot be open to question. Every picture, whether motion or otherwise, is a visual representation of the thing it depicts." In view of the apparently meaningless phrase, "television rights unaccompanied by visual representation," it would appear that a solution of the verbal factors in the controversy would be of little assistance. Apparently recognizing this, Judge Byrne went on to say (p. 559), "Just what uses of television were foreseeable in I93I is open to conjecture, but conceivably the parties could have contemplated recitals of the play without the picture. That would be an audible representation unaccompanied by a visual representation of the play."

In 1949 the Superior Court of Los Angeles County ${ }^{34}$ held that a performer, having failed to reserve television rights in his performance, had granted them to his employer by virtue of his status as an employee. One wonders whether that status alone would have permitted the employer to film and exhibit a motion picture or

\footnotetext{
${ }^{28}$ Accord: Murphy v. Warner Bros. Pictures, Ix2 F. 2d 746 (9th Cir. 1940); G. Ricordi \& Co. v. Paramount Pictures, 92 F. Supp. 537 (S. D. N. Y. 1950); Kirk La Shelle Co. v. Paul Armstrong Co, 263 N. Y. 79,188 N. E. 163 (1933), sometimes cited as contra, did not in fact decide that motion picture rights exclude talkie rights, but turned on an implied negative covenant, and is discussed later.

${ }^{30}$ L. C. Page \& Co. v. Fox Film Corp., 83 F. 2d 196, at 199.

31 108 F. Supp. 558 (S. D. Calif. 1952).

${ }^{32}$ Sic. Id. at 558-559.

${ }^{33} \mathrm{An}$ appeal is now pending and undecided before the Ninth Circuit Court of Appeals.

34 Peterson v. KMTR Radio Corporation, Superior Court Case No. 453,224 , reported in 18 U. S. L WEEK 2044 (U. S. July 26, r949). This case dealt with performer's rights. It is pertinent only by analogy. On this general subject, see Silverberg, Televising Old Films-Some New Legal Questions about Performers' and Proprietor's Rights, 38 VA. L. REv. 6 I5 (I952).
} 
to make a phonograph recording in the absence of an express reservation of such picture rights by the employee. ${ }^{35}$

Autry v. Republic Productions, ${ }^{36}$ and Rogers $v$. Republic Productions, ${ }^{37}$ were decided by different judges of the same court within a few months of each other, on substantially similar facts. The decisions are in conflict. Both decisions illustrate the manner in which the economic influences being brought to bear in television have brought about disputes in the interpretation of literary property documents; and the conflicting conclusions demonstrate the lack of convincing guideposts in this field. ${ }^{38}$

Autry, as an employee of Republic, had performed in numerous films produced by his employer. He urged, however, that Republic did not have the right to license the films for commercially sponsored television broadcasts on the ground that such broadcasts constituted a use of the film for advertising purposes. Judge Harrison gave judgment for the defendant, holding that Republic's right to use the film had not been restricted by its contract with the plaintiff.

It should be noted that Autry did not claim any ownership of the film, and did not contest Republic's right to use the films on television generally; he argued that Republic had no right to use the films on sponsored television, on the ground that such use constituted commercial advertising. "Plaintiff in effect tells defendants they may televise the photoplays involved provided their exhibition is without sponsorship. This graciousness on behalf of the plaintiff can be readily evaluated when one realizes, as a practical matter this would preclude Republic's use or sale of photoplays in which plaintiff appeared."39 Commenting on the argument that on television the film is continually "punctuated with advertisements," Judge Harrison said, "The evidence discloses that 'spot advertising' is common practice in most conventional motion picture theatres. Television is also punctuated with advertisements. In principle there is no practical difference. . . . The close proximity of said advertisements to the photoplay is something beyond the control of the plaintiff. It is a matter of common knowledge that pictures intermingled with advertisements flow constantly over the television screen. It is difficult to segregate one sponsor from the other, except where the advertisement is interwoven into and made a part of a television picture." 40 Without professing to question the decision, it is easily conceivable that breaking the continuity of a film, and thus of the performance, for advertising inserts could make a substantial difference; to say that this beyond the control of an artist begs the question, for licenses can by appropriate language restrict the manner of exhibition.

The findings and conclusions of law in the Rogers case have been published, and disclose the holding of the court: notwithstanding that Republic was given the

\footnotetext{
${ }^{36}$ The decision is discussed at length and criticized in HenRy S. WARnER, Radio and Television RiGHTS 216 (I953).

${ }^{30} 104$ F. Supp. 918 (S. D. Calif. 1952). $\quad{ }^{37}$ 104 F. Supp. 328 (S. D. Calif. x952).

${ }^{38}$ These decision deal with the rights of performers, but it it believed they merit careful consideration as pertinent by analogy.

${ }^{30}$ t0 4 F. Supp. 918, at 922.
} 
right by contract to televise the motion pictures in which Rogers appeared, this right was, by other language in the contract, restricted so as to forbid the use of the films for commercial advertising. Perhaps most significant is the determination that the use of films on television (and presumably anything else, whether an actor, music, or literary work) is a use for advertising purposes. ${ }^{41}$ The judgment permanently enjoined the exhibition of the films on sponsored or sustained television because in either such case exhibition was for the purpose of commercial advertising.

The Rogers and Autry decisions turned on the construction of the respective contracts, and they may not control the solution of other controversies. ${ }^{42}$ Their importance lies in the recognition of the economic realities of television exhibitionthat entertainment over television is, under present conditions, inseparably wedded to advertising. Thus it appears that a branch of the law of literary property, which will grow in importance as television grows, reaches over into the fresh and luxuriating tangle of the law of commercial exploitation. An author, who in the past justifiably expected that the motion picture produced from his novel or play would be exhibited as a whole, may be required to view segments of it interspersed with the art of car salesmen and hairdressers.

Whether use of the film on television constitutes use for advertising purposes may be put at rest by the Ninth Circuit Court of Appeals when the Rogers and Autry appeals are decided. The question is important for television use. The Fifth Circuit ${ }^{43}$ has held that the publication of a still photograph on a calendar advertising beer could not reasonably be construed to represent that the subject of the photograph endorsed or recommended the product.

Under the New York privacy statutes ${ }^{44}$ it has been held that an unauthorized telecast of a public performance is not a use "for advertising purposes" within the meaning of those statutes. ${ }^{45}$ The court said $:^{46}$

The unique economic necessities of radio and television, however, require that, in large part, programs appear under the sponsorship of commercial advertisers. To hold that the mere fact of sponsorship makes the unauthorized use of an individual's name or picture on radio or television a use "for advertising purposes" would materially weaken the informative and educational potentials of these still developing media. We hold, therefore, that in the absence of exploitation of a name or picture in the commercial announcement or in direct connection with the product itself, there is no use "for advertising purposes."

41 ro4 F. Supp. 328, at 336.

12 Literary property licenses often contain restrictions on use of the work for advertising purposes; how such a restriction might affect the right to use the work for television purposes raises interesting, but as yet undetermined, questions.

${ }^{43}$ O'Brien v. Pabst Sales Co., I24 F. $2 d$ 167 (5th Cir. 1941).

"N. Y. Civil Rights Law $\$ \$ 50-52$ (I948).

¿5 Gautier v. Pro-Football, 278 App. Div. 43T, 106 N. Y. S. 2d 553 (Ist Dep't 195I), af'd, 304 N. Y. 354,107 N. E. 2 d 485 (1952).

${ }^{\circ}$ Id. at 557. It should be borne in mind that the privacy statutes have long been construed to mean that the business or trade for profit in newspapers, newsreels, and other informative vehicles, docs not bring such media within the privacy statutes. Humiston v. Universal Film Mfg. Co., 189 App. Div. 467,178 N. Y. Supp. 752 (Ist Dep't 1919). The holding under those statutes is, therefore, not neccssarily applicable to the construction of literary property documents. 
Pennsylvania has held, in construing a police statute, that the phrase "motion pictures" includes television, ${ }^{47}$ even though television was unknown when the statute was passed. And an opinion of the Attorney General of Florida requires candidates to report television expenses under a statute which refers only to "radio" expense." These interpretations properly ignore differences in the media which are not germane to the purposes of the respective statutes. They have, however, been cited in construing inter-party literary property transactions.

An examination of the principal factors in the foregoing literary property controversies discloses the following: a transfer of some rights, less than the whole, in literary property; and the subsequent development of a new use. The licensee may claim that the new use was included in the early assignment; or he may claim that the exercise by another of the new use would diminish the benefits intended to be assigned. The courts most often have examined the words of the assignment and have decided the litigation upon determining whether or not the new use had been licensed. Often, however, when the instruments have been construed to mean that the right to the new use had not been conferred, the courts have found that such a solution did not meet the argument that the exercise of the new use by the owner or by a subsequent licensee would in some measure defeat the earlier license. For example, if it were found that a license of motion picture rights did not include television use, it could be argued that a live telecast of the same story would deprive the holder of the motion picture rights of the full benefit of the license.

The courts have occasionally recognized the validity of this argument and have found that although the right to the new use had not been conferred, and thus had been retained by the owner, justice required forbidding the exercise of the new use without the consent of the licensee. The law would imply a covenant on the part of the owner not to impair his grant. This paper refers to that rule in its various forms as the "implied negative covenant" doctrine. It has already been referred to in some of the television decisions, ${ }^{49}$ and no doubt will influence literary property law in the future.

Very early after motion picture rights came to be valuable, a lower New York court recognized the economic consequences of motion pictures on prior grants of production rights. ${ }^{50}$ The court had before it a contract written in Igoo which granted the exclusive right to produce a play in theatres of specified classes. Heirs of the author later granted motion picture rights to another. In the litigation, the heirs argued that since the author and licensee could not in I900 have known about motion picture rights, those rights were not then licensed and must have been retained by the author. The court rejected the argument and gave judgment against the heirs. "That by the aid of science it has, since the contract was executed, been

\footnotetext{
${ }^{47}$ Philadelphia Retail Dealers Ass'n v. Pennsylvania Liquor Control Board, 360 Pa. 269, 62 A. 2d 53 (1948).

4 Feb. 15, 1952, No. 052-40, cited in 12 Fed. CoM. B. J. 296 (Autumn I952).

${ }^{4} \mathrm{Cf}$. Wexley v. KTTV, I08 F. Supp. 558 (S. D. Calif. 1952).

${ }^{t 0}$ Frohman v. Fitch, I6 64 App. Div. 231 , I49 N. Y. Supp. 633 (Ist Dep't I9I4).
} 
made possible to produce the play in some manner not then contemplated, does not give William G. Fitch nor the American Play Company the right to destroy plaintift's property or diminish the value of what he purchased." that the court had resolved the question of construction against the author's heirs, and it was not necessary to find a negative covenant in order to protect the holder of the dramatic rights.

The doctrine came more clearly into the literary property cases in Harper Bros. v. Klaw. ${ }^{52}$ That decision again arose from a dispute as to whether the right to dramatize included the right to make a motion picture; the work involved was the novel Ben Hur; the contract had been executed in I899. Judge Hough found that the instrument had not conferred upon the licensee the right to make motion pictures, and he enjoined the defendant. But he did not stop there; he granted a "double injunction," forbidding both the plaintiff and the defendant to make any motion pictures without the consent of the other. While holding that plaintiff had retained the motion picture rights, he went on to say (p. 6r3):

... it does not always follow that, because one owns a certain thing, he may use it to the detriment of another, especially if the owner is under contractual obligations to such other. ... In my opinion there is implied a negative covenant on the part of the plaintiffs (the grantors of defendants' restricted license) not to use the ungranted portion of the copyright estate to the detriment, if not destruction, of the licensees' estate. Admittedly, if Harper Bros. . . . permitted photoplays of Ben Hur to infest the country, the market for the spoken play would be greatly impaired, if not destroyed. (Emphasis supplied.)

It is not clear whether the "contractual obligations" referred to were merely the privity of contract, or the implied negative covenant, or whether the covenant arose from some other, but undisclosed, contractual obligations. ${ }^{53}$

A few weeks after the decision in Harper Bros. $v$. Klaw, another judge of the same court distinguished the case before $\mathrm{him}^{54}$ on the ground that the contract involved had been executed in IgIx; and he implied that since the grantee must have known of the existence of motion picture rights, the latter consented to taking the dramatic rights subject to the grantor's unexpressed reservation of motion picture rights. In discussing the possible impairment of the dramatic right, he said (p. 246) : "I am far from satisfied that every motion picture interferes with the box office receipts from the same play on the dramatic or operatic stage. I imagine that the motion picture 'Carmen' will not outlast the living opera." Thus, the critical question of fact, which lies at the root of the doctrine of implied negative covenant, was pointed out; but it does not appear either in that case or in any other that evidence was received on the question.

${ }^{51}$ Id. at 634 .

52232 Fed. 609 (S. D. N. Y. I916).

E3 The only precedent cited is 2 JAMEs L. High, A TrEatrse on THE LAW OF INJUNCTIONS (51151(a)) Ir33-ri34 (4th ed. I905), and the principle that "a covenant to make a certain use of property" implies "a covenant negative against doing anything else with it;" that is to say, an obligation on the part of the licensee to refrain from exercising an unlicensed privilege.

${ }^{6}$ Klein v. Beach, 232 Fed. 240 (S. D. N. Y. Igr6). 
The decisions in the Peg $O^{\prime} M y$ Heart cases offer perhaps the best illustration of the uncertainty and travail which finally brought about the sanction of the doctrine by the Supreme Court of the United States. ${ }^{55}$ The playwright J. Hartley Manners had granted to Morosco the exclusive license to produce and present the play. In the litigation, Manners sought to enjoin Morosco from exercising motion picture rights. The District Court treated the issue solely as a problem of construction; and while it took note of the financial consequences of alternative constructions, ${ }^{50}$ the court's observations were for the purpose of seeking the meaning of the language used. It found that the contracts had licensed the production of motion pictures. The Court of Appeals affirmed by a divided court. That court, too, regarded the issue as one of construction only, and the majority said so. ${ }^{67}$ Although Judge Hough (who had decided Harper Bros. v. Klaw and had given express recognition to the implied negative covenant doctrine), participated with the majority in Manners v. Morosco in the Circuit Court of Appeals, no mention is made in that opinion of the doctrine. ${ }^{58}$ Perhaps Judge Hough, sitting on the Court of Appeals, was not sufficiently confident of the doctrine to bring it before the other Judges of that court.

The Supreme Court, again by a divided court, reversed both the lower courts. Holmes said, for the majority, that the motion picture rights had not been licensed to Morosco, and thus were retained by Manners; but, after quoting Judge Hough's language in Harper Bros. v. Klaw, Holmes concluded: ${ }^{59}$

The result is that the plaintiff is entitled to an injunction against the representation of the play in moving pictures, but upon the terms that the plaintiff also shall abstain from presenting or authorizing the presentation of the play in that form. ...

The doctrine of the implied negative covenant has had an uncertain career since Manners v. Morosco. An examination of the literary property decisions in which the doctrine has been discussed ${ }^{60}$ leads to the inference that the doctrine is not always understood to mean the same thing, has not been uniformly applied, has been a last resort in difficult cases, and has in some instances been rejected for the wrong reasons. For example, in Underhill $v$. Schenck ${ }^{61}$ the court, faced with the argument that the production of a motion picture would unfairly compete with the

${ }^{20}$ Manners v. Morosco, 254 Fed. 737 (S. D. N. Y. rgr8), 258 Fed. 557 (2d Cir. I919), 252 U. S. 317 (1920).

254 Fed. at 742 .

2728 Fed. at 559 .

${ }^{88}$ This is all the more surprising in view of the fact that when the case reached the Supreme Court of the United States the sole decision cited for implied negative covenant was Judge Hough's decision in Harper Bros. $v$. Klaw.

${ }^{80} 252$ U. S. at $32 \%$.

${ }^{60}$ E.g., Gillette v. Stoll Film Co., 120 Misc. 850, 200 N. Y. Supp. 787 (Sup. Ct. 1922); Amusement Securities Corporation v. Academy Pictures Distributing Corp., I62 Misc. 608, 294 N. Y. Supp. 279 (Sup. Ct. I936), aff'd, 250 App. Div. 910, 294 N. Y. Supp. 305 (Ist Dep't I937), modified, 25 I App. Div. 227, 295 N. Y. Supp. 436 (Ist Dep't I937), and affirmed as modified, 277 N. Y. 557, 13 N. E. 2d 47 I (1938); Kirk La Shelle v. Paul Armstrong Co., 263 N. Y. 79, I88 N. E. I63 (1937); Macloon v. Vitagraph, 30 F. 2d 634 (2d Cir. 1929).

${ }^{1}{ }_{14}$ Misc. 520, 187 N. Y. Supp. 589 (Sup. Ct. I92I). 
dramatic rights granted to the plaintiff, distinguished Manners $v$. Morosco on the ground that the latter decision had involved a copyright violation, a distinction not logically relevant to the question whether the license contained a negative covenant by implication.

However, it is likely that the doctrine will be revived in television-versus-motionpicture-rights disputes and that the courts will be called upon to re-examine it. For these reasons it may be useful to examine its origin and rationale more closely.

It is usually said in the abstract that covenants will not be implied unless indispensable to effectuate the expressed intention. ${ }^{62}$ In a recent decision in which appellant sought to imply a covenant it was said: ${ }^{63}$

Nothing may be added by way of implication except that which is necessary to carry out the intentions of the parties, as derived from the agreement itself and not merely from the circumstances under which it was made.

Literary property decisions have justified application of the doctrine on the maxim that a grantor may not be permitted to derogate from his grant. Two English decisions ${ }^{64}$ are often cited as early authority for that principle in its most general terms. ${ }^{65}$ Seddon $v$. Senate held that a sale of the formula for a proprietary medicine and of a copyright of a treatise on medicine carried with it, though no such covenant was expressed, an implied obligation that the seller would not himself manufacture the medicine, and that a breach of that implied obligation could be declared upon as a breach of covenant. Because the assignor had parted with the formula, his unauthorized manufacture would have constituted an infringement in any event; and the opinions of the justices do not clearly distinguish between infringement and breach of the implied negative covenant. Gerard $v$. Lewis, is similar in principle; ${ }^{00}$ and the text writers state the principle narrowly ${ }^{67}$ in terms forbidding a grantor to derogate from his grant. It should be observed, however, that in the literary property cases the doctrine has been stretched beyond derogation from the immediate scope of the grant; the doctrine has been applied not to implement the grant, as in Seddon $v$. Senate, by an implied covenant, but to prevent exercise of another right found by the court to be competitive with the right granted, though outside the grant itself.

A variant is another maxim which is held to give rise to an implied covenant.

${ }^{62}$ Churchward v. The Queen, L. R. I Q. B. I73 (1865); Delaware and Hudson Canal Co. v. Pennsylvania Coal Co., 8 Wall. 276 (U. S. 1868 ); Quader-Kino A. G. v. Nebenzal, 35 Cal. 2d 287, 217 P. 2d 650 (1950).

${ }^{63}$ Sharpe v. Arabian American Oill Co., III Cal. App. 2d 99, 244 P. 2d 83, 85 (1952); and see Macloon v. Vitagraph, 30 F. 2d 634 (2d Cir. I929).

${ }^{6}$ Seddon v. Senate, 13 East 63 , I04 Eng. Rep. 290 (K. B. 1810); and Gerard v. Lewis, L. R. 2 C. P. 305 (I867).

os Hamilon, The Law of Covenants 44 (London, 1904); Thomas Platt, a Practical Treatise on the Law of Covenants 25 ( 1834 ).

${ }^{00}$ Defendant, assignor of a chose in action, thwarted his assignees' efforts to collect from the debtor by procuring the debtor's release from arrest for debt; it was held that the defendant had violated the implied covenant.

${ }^{77}$ See W. A. Jolly, Restrictive Covenants Affecting Land gi (2d ed., London, 193i). 
"Where a party stipulates that another shall do a certain thing, he thereby impliedly promises that he will himself do nothing which may hinder or obstruct that other in doing that thing." 68 This maxim may simply be a different form of the principle against derogation from a grant. From this maxim it has been argued in literary property cases that the licensor of certain rights would impair the licensee's use of those rights by a subsequent license of other rights. However, in other branches of the law the maxim is not construed thus broadly. For example, a landlord, having let a portion of the premises for one use, is under no implied obligation to refrain from the letting another portion for the same or for a competing use, ${ }^{\infty 0}$ or otherwise to restrict the use of other portions of the premises. ${ }^{70}$ Certainly a manufacturer or distributor is under no implied obligation to refrain from making his products available to competitors of earlier customers. It is not reasoning but circumstance, unexpressed in the literary property decisions, which accounts for the different application of this principle to those cases. It is not too much to infer that the circumstance is the new use, unforeseen by the parties when the contract was made.

Negative covenants have been implied in some varieties of personal service contracts where there is an affirmative obligation to render exclusive services. ${ }^{71}$ It has also been held that such covenants will not be implied, and no injunction would issue in the absence of express negative covenants, even though the services be unique. $^{\boldsymbol{7 2}^{2}}$ Negative covenants have been implied in cases involving exclusive-service employment in the production of literary works, ${ }^{73}$ because they entitle the employer to the whole of the employee's services. These situations parallel assignments of all rights in literary property cases, though for a limited period. However, the decisions in personal service contracts are not persuasive as analogies in any event, because they have involved direct competition in the very field of work expressly made the subject of the prior employment contract. Thus, a singer is enjoined from singing for another employer, ${ }^{74}$ or a writer is enjoined from writing for another employer. ${ }^{75}$ More nearly parallel would be a decision enjoining a performer from appearing on a series of television programs because he had previously contracted for exclusive

${ }^{08}$ Gay \& Co. v. Blanchard, 32 La. Ann. 497 (I880); Patterson v. Meyerhofer, 204 N. Y. 96, 100, 97 N. E. 472,473 (1912), quoting from Gay \& Co. v. Blanchard, supra, at 504.

${ }^{00}$ Sherrer v. Sparks, 78 S. W. 2d (Tex. Civ. App.) ro35 (r935).

${ }^{70}$ Hannan v. Harper, I89 Wis. 588, 208 N. W. 255 (I926); Henlun Holding Corp. v. Ess Bros. Holding Corp., 228 App. Div. 102, 239 N. Y. Supp. 257 (Ist Dep't 1930).

${ }^{71}$ Louis D. Frohlich and Charles Schwartz, The Law of Motion Pictures, Including the Law of the Theatre, Treating of the Various Rights of the Author, Actor, Professional Scenario Writer, Director, Producer, Distributor, Exhibitor and the Public, with Chapters on Unfair Competition, and Copyright Protection in the Untred States, Great Brttain and Her Colonial Possessions 99 et seq. (I9r8).

${ }^{72}$ Madison Square Garden Corp. v. Braddock, 90 F. 2d 924 (3d Cir. r937); Burton v. Marshall, 4 Gill 487,45 Am. D. I7I $(1846)$.

${ }^{73}$ Didier v. Macfadden Publications, 80 N. Y. S. 2d 409 (Sup. Ct. I948); Star Co. v. Press Publishing Co., I62 App. Div. 486, I47 N. Y. Supp. 579 (Ist Dep't I9I4).

${ }^{7}$ Lumley v. Gye, 2 E. \& B. 216 , 118 Eng. Rep. 749 (Q. B. 1853 ).

${ }^{75}$ See note 73 , supra. 
motion picture appearances. But that decision has not yet been rendered, so far as known to this writer.

Patent cases promise closer analogies ${ }^{76}$ and indeed offer a few which are relevant to the question of obligations implied in a licensing agreement. A non-exclusive licensee may use competing devices and thus diminish his obligation to pay royalties, ${ }^{77}$ but an exclusive licensee who pays for his license by royalties may not do so. ${ }^{78}$ However, it is also held that there is nothing to prevent a licensee from accomplishing his ends outside the scope of the license, and thus escaping the payment of royalties. $^{79}$ The closest analogy would arise in the situation in which a license is granted without an express agreement (contrary to uniform practice) affecting the licensee's rights to the use of improvements afterwards invented and patented. If the reasoning of the implied negative covenant of the literary property cases was applied, the patentee should not be permitted to license his improvement to a third person, because such a license would derogate from the prior license under the original patent. However, no such doctrine appears in the patent law, and the inference is to the contrary. There is no implied covenant that the licensee is entitled to the use of subsequent improvements. ${ }^{80}$

This writer's opinion of the application of the negative covenant doctrine to literary property cases will have become manifest to the reader before he reaches this point. Precedent cannot account for its role in literary property cases; analogy does not support it. To deprive an author of the right to exploit a work by means of one use solely because he has previously licensed the work for another use, rouses the "sense of injustice" which Professor Cahn has written about.

The doctrine appears, as this writer has suggested, to have been the result of groping toward justice under difficulties brought about, not by the parties themselves, but by the advance of techniques. To criticize the application of the doctrine is not to deny the existence of the difficulties which called it forth. But whatever the just solutions may be, and there may be several, the doctrine of the implied negative covenant, based solely on the existence of a prior license for the same work, is not among them.

In résumé: the refusal of the courts to permit the development of new uses to

${ }^{70}$ There are important distinctions in principle; a patent confers a true monopoly; a copyright, by contrast, does not restrain the exploitation of even an identical work, if produced independently; furthermore, the scope of the originality is, in our patent system, defined by the Patent Office, while a copyright merely registers a claim.

${ }_{77}$ American Sealcone Corp. v. Sylvan Seal Milk, 42 F. Supp. 480 (E. D. Pa. 194x); Clancy v. Troy Belting and Supply Co., 157 Fed. 554 (2d Cir. 1907).

${ }^{78}$ Mechanical Ice Tray Corp. v. General Motors Corp., I44 F. 2d 720 (2d Cir. 1944), cert. denied, 324 U. S. 844 (1945).

${ }^{79}$ Lanova Corp. v. Atlas Imperial Diesel Engine Co., 5 Terry (Delaware) 55, 55 A. 2 d 272 (1947).

${ }^{80}$ Plastray Corp. v. Cole, 324 Mich. 433, 37 N. W. 2d r62 (r949); De Stubner v. United Carbon, 67 F. Supp. 884 (S. D. West Va. 1946), affd. 163 F. 2d 735 (4th Cir. 1947), cert. denied, 334 U. S. 829 (1948); May v. Page, 60 N. Y. 628 (1875); and cf. Stokes \& Smith Co. v. Transparent-Wrap Machine Corp., 156 F. 2d 198 (2d Cir. 1946), reversed, 329 U. S. 637 (1947), on remand, 161 F. $2 \mathrm{~d}$ 565 (2d Cir. 1947), discussing legality of an express agreement by a licensce to assign to the patentec any improvement patents issued to licensee. 
disturb the effect of assignments of all rights seems logical and just. In those situations the subject of the transfer is the work itself; the discovery of a new and valuable use should no more affect the transfer of the work than would a subsequent decree holding the work obscene and unmarketable. The risk follows the transfer.

New uses arising in the cases of licenses have, on the other hand, presented the courts with grave difficulties which have not always been happily solved by resort to the language of the instruments or by the application of the awkward doctrine of implied negative covenant. To illustrate, the injunction in Harper Bros. $v$. Klaw could result in suppression of the motion picture rights during the copyright period, because the defendant had the unconditional right to refuse to agree to licensing. In Manners $v$. Morosco, the injunction granted to the plaintiff was conditioned on his abstaining from exercising or licensing the motion picture rights; if plaintiff violated the condition, defendant could then exercise the motion picture rights, presumably without cost.

New use problems in literary property cases will no doubt be before the courts for years, particularly in conflicts between motion picture rights and the newer visual remote-audience techniques, of which current television may well be a preliminary and rudimentary form. It is worth trying to state some of the lessons learned from the earlier decisions.

The "new use" problem is essentially not one of construction at all, and it should be so recognized and dealt with. The problem is created, not by the cupidity or contrariness of the parties, nor by the ambiguity of language, but by the advent of an unforeseen circumstance freighted with important economic significance. As Judge Hough said in Harper Bros, v. Klaw, ${ }^{81}$ of motion picture rights, then a new use, ${ }^{82}$

... they are an accretion or unearned increment conferred of late years upon the copyright owners by the ingenuity of many inventors and mechanicians.

It is possible that a licensing agreement, though limited as to use, may nevertheless by its language embrace uses not known to the parties at the time the paper is signed. Thus, a license for "all printing and publication rights, whether now known or unknown, including methods and forms hereafter conceived," would leave no doubt that the parties intended to embrace methods of printing, book binding, and varieties of publications not then known to the parties. However, the terms of a licensing agreement cannot often furnish a clue to the solution of the problems raised by a new use. By definition the new use was not known when the instrument was drawn, and unless general terms are employed in the agreement the new use cannot have been within the contemplation of the parties. To attribute a meaning, unknown and unknowable to the parties, to the words they wrote in an agreement is indeed to revert to animism and to act as though ink and paper could bring about results independent of the purpose of the parties. For this reason it should be recognized that the problem presented is not whether the new use was or was

${ }^{81} 232$ Fed. 609 (S. D. N. Y. 19I6).

${ }^{83}$ Id. at $6 \mathrm{r3}$. 
not caught up in the chance use of language; the problem is not one of construction at all because (except in those instances in which general language is employed to express a different intention) the new use could not have been a subject of contract.

The question for decision then becomes: should the licensor or assignor, having issued one license, be free to exercise or license to a third person a new and competing use. The question is no longer one of express contract. It is a question whether a court in the exercise of equitable discretion should exact new obligations and impose new duties.

The use of motion picture film, produced under a motion picture license, for television would raise such a question if the license failed, contrary to customary practice, to state that the licensee had the unrestricted right to use the film in any manner whatever. ${ }^{83}$ While the use of the word television came into literary property documents as early as 1915 , it was not in common use until after 1930; and no doubt many motion picture licenses were issued without any thought of television use. Eliminating those licensing instruments which solve the problem by express language, the question raised is whether the holder of motion picture rights in a work should be permitted to exhibit the motion picture over television. It might suffice to say that because the television use had not been licensed it was retained. However, the economic consequences of a negative answer would be more cogent. The one factor-admittedly a powerful one-which earns for the holder of the motion picture rights a position better than that of a stranger is the fact that he has produced a motion picture of the work. If the television use is held to have been retained by the author, and if a license for telecasting a motion picture of the work were offered generally, then in any competition for such a license the holder of the motion picture license and of the photoplay would hold the bargaining position which the quality and success of the previously produced motion picture photoplay had earned; if a successful production, the author would prefer that it rather than another be exhibited; even if it be a tolerably profitable production, it would have the advantage of being completed and presumably would be at least as well done as most current television productions. In place of the inflexibility of a legal presumption and its limited alternatives of ownership or non-ownership of television rights, there would be substituted the economic force of the situation with all of the gradations made possible by negotiation. It is no argument that the holder of the motion picture license would have to pay additionally for the television use; such a use is a source of revenue which is a windfall to both author and licensee, and no injustice appears in requiring that it be shared.

A question arises from the common practice of recording "live" television performances on film. Would this conflict with an earlier motion picture license of the work? This writer would consider the question in terms of its economic consequences. If the kine or T.V.R. were prepared and used solely for record purposes, and not exhibited except as incidental to maintaining a record, the question be-

${ }^{83}$ See Iturbi v. ABC-TV, reported in Daily Variety, Dec. 3, 1953. 
comes academic, because film in the vault earns nothing and cannot interfere with the motion picture license. However, if the film were later telecast, the question resolves itself into the one discussed above; whether, in the narrow hypoethetical circumstances stated, the earlier motion picture license includes the right to telecast the film.

The foregoing ignores the implied negative covenant argument, but only for the purpose of considering that argument more fully.

The important practical consequence of the implied negative covenant decision was to prevent competition from another use of the same work. The holder of dramatic rights of a novel was, by the injunction, protected from the competition of a subsequent motion picture based on the same novel.

The instances in which injunction has been granted deserve closer examination. The implied negative covenant doctrine has not been applied where there has been a transfer of the work or copyright (or an assignment of all rights); the doctrine has been applied only in those cases in which an exclusive license for a specified use has been issued. This distinction seems important. In the license cases it may be inferred that the parties contemplated that other uses, at least to the extent then known, would be exercised by the author or by others. Accordingly, it is reasonable to conclude that the licensee could not expect that he would exercise his license without competition from other uses of the same work, at least to the extent then known. And if this is true, the implied negative covenant, as applied, appears unsound because it aims at preventing such competition. To illustrate: if certain stage rights in a play were licensed in rgoo, it is reasonable to conclude that the licensor must have anticipated competition from other stage rights as well as from published versions of the work. But the Supreme Court held in Manners $v$. Morosco that a motion picture version of the play could be produced only if the licensee of the stage rights were given a license to produce a motion picture.

If the foregoing is true, there still remains for consideration the question whether the "new use" is so close to the use previously licensed as to make it inequitable to permit the author to benefit from the new use to the detriment of his licensee. (It is worth repeating that at this point in the discussion this writer has eliminated from consideration those instances in which the license previously issued can logically be held to have embraced the "new use.") It seems strange doctrine to forbid the exercise of a new use solely on the ground that it would compete with an earlier license essentially different in nature. Whether a television use of a work is essentially different from a photoplay of the work or is so nearly the same as to justify an injunction is a question on which reasonable minds deliberating from the armchair might differ. It is submitted that comparisons based on technical factors would miss the fundamental problem. In the common case the motion picture license was issued and received with economic ends in view; and the controversy between the licensee of motion picture rights and the subsequent licensee of television rights is presumptively an economic one. Traditional principles of equity are probably sufficient for a solution of the problem in such a case. The applicant for an in- 
junction, that is, the holder of the motion picture rights, would be required to show a substantial impairment of the benefits reasonably contemplated from the motion picture license. This is to say that the reasons heretofore stated by the courts as the basis for the implied negative covenant should be dealt with, not as rules of law justifying injunction simply by resort to a maxim, but as questions of fact. In any case in which a contention is made that the projected television use would undo the benefit reasonably expected by the parties when a motion picture license was granted, issues should be framed and evidence received to determine whether the particular television use would indeed derogate from the author's license of the motion picture use, and thus impair the benefit rightly expected from the motion picture license. Such a license previously granted may have exhausted its economic life, even though the term of the license had not yet expired. The motion picture photoplay previously produced may have become dated and unsalable, and re-issue would earn no profit. A new version of the same film, even if permissible under the motion picture license, may be too costly and thus unsound, and may not even be contemplated. These and countless other factors may well compel the conclusion that, under traditional equitable principles, no injunction should issue; that damages may be an adequate remedy; or even that merely nominal damages would be justified.

What has already been said is pertinent equally to the question whether a telecast of a live television performance would conflict with a prior motion picture license. Arguments based on superficial similarity, that is, that the audience in each case views a moving image on a screen, and arguments based on the happy choice of phraseology prior to the existence of television, would not solve the problem on a basis which is meaningful for the litigants. Without excluding the weight of other factors, the question whether a negative covenant ought to be implied should, it is submitted, be considered in the light of economic issues framed and evidence received.

It is a commonplace that television is regarded by many as a threat to some aspects at least of the motion picture industry, from production of the film to operation of theatres for exhibition. This attitude will surely be felt in the courtroom. Just as the advent of motion pictures brought forth the negative covenant doctrine for the purpose of helping the living drama to survive, under the influence of such an attitude the words in title and use documents will polarize, and it is reasonable to expect that meanings will be found which the parties did not put into the documents. Furthermore, lawyers and judges will look for principles by which to ameliorate the disturbances and losses thought to be caused by the "new use." Nothing in this article should be construed as critical of such efforts. It would be unfortunate only if such influences were erroneously rationalized as problems in construing old documents, and it would be doubly unfortunate if the genuine economic issues at stake in such litigation were suppressed under misapplied equitable principles, instead of being stated openly, examined by the use of evidence, and applied or rejected as justice required. 